\title{
The Mediating Effect of Employee's Trust on E-government and Good Governance in the Public Sector of Developing Countries
}

\author{
Hassan Alaaraj (Corresponding Author) \\ School of Economics, Finance and Banking, University Utara Malaysia \\ 06010 UUM Sintok, Kedah Darul Aman, Malaysia \\ E-mail: araj.hassan@hotmail.com
}

Professor, Dr. Fatimah Wati Ibrahim

School of Economics, Finance and Banking, University Utara Malaysia

06010 UUM Sintok, Kedah Darul Aman, Malaysia

E-mail: fatimah@uum.edu.my

DOI:10.5296/ ijld.v4i3.6460 URL: http://dx.doi.org/10.5296/ ijld.v4i3.6460

\begin{abstract}
The main purpose of this paper is to study the mediating effect of employee's trust between e-government and good governance in the public sector of the developing countries. In addition, it presents a conceptual research framework to understand these relationships supported by literature review from recent studies. The main findings indicate that empowering public sector employees through practicing e-government creates trustworthy behaviors which are necessary to promote effectiveness, efficiency, transparency and innovativeness as means of good governance. Implications and limitations of the study are also discussed where future studies are recommended to extend the research empirically and highlight more on governments of developing countries which are in need to such kind of transformation for an effective economic reform.
\end{abstract}

Keywords: E-government, trust, good governance, public sector. 


\section{Introduction}

The deteriorate performance of governments in developing countries is mainly evidenced by the high level of corruption and the decline of service quality delivered by the public sector. In addition to the limited infrastructure and financial capabilities such poor performance is as result of the irresponsible actions taken by decision makers, the lack of employee's trust, work ethics and commitment toward the tasks they should proceed (Phang, 2008). The widely spread corruption that is striking the public sector in developing countries is not only reflecting the poor strategies and policies in these countries, but also revealing the failure of good governance implementation (siddiquee, 2009). Any act of corruption such as not being transparent and not providing the service efficiently and effectively is seriously considered as a kind of abusing the government resources to an extent that would lead to reflecting a bad image about the government. Hence, there is a need for transparent and accountable governments that are able through their employees to use the resources efficiently and responsibly to deliver quality services for the public benefits.

UNESCAP (2012) defines governance as how to make the decision and by which process it is implemented, where it generates valuable outcomes that match the needs of the community through the efficient use of the resources. Also, Khan (2013) related the term of good governance to the contribution of public administration and polices and the development of strategies at the level of efficient administration. Thus, good governance is a combination of high-order actions which stand in context with the administrative and managerial activities at the organization. Such actions including innovativeness, legitimacy, transparency, efficiency, openness, accountability, fairness, commitment, security, regulation and others were discussed by several researches (UNESCAP, 2012; Iwu-Egwuonwu, 2011; Ruhanen et al., 2010; Rachagan, 2010; Shean, 2010; UNDP, 2008; Jalaluddin \& Azmizam, 2009; pillay, 2004). However, pillay (2004) identified accountability, transparency, high standard of professional ethics and openness as the main principles of good public sector governance.

Based on different studies, governance is defined as corporate and political science based categories. It is corporate governance when it is related to the internal environment of the organization at private sector particularly, while political science based governance is more influenced by the external environment of the organization (Ruhanen et al., 2010). As governments in developing countries tend to adapt organizational trends from private sector, corporate governance principles were employed through the public sector organizations to perform more effectively and efficiently (kluvers \& Tippett, 2010). Thus, governance applied by government is called public sector governance (ANAO, 2003). Moreover, when employees of public sector perform their tasks and utilize the optimum level of resources effectively and efficiently in producing the desired outcomes, then governance is called good governance. It plays a significant role in providing stability and growth at the macro-level of the economy (Rachagam, 2010).

Therefore, the governments of developing countries have taken the initiative in implementing new strategies and providing supportive environment for the diffusion of incremental innovations, such as the electronic government (e-government) to increase and sustain good 
performance among the public sector. E-government refers to "the utilization of Information and Communication Technologies (ICTs) and other web-based telecommunication technologies to improve and enhance the efficiency and effectiveness of service delivery in the public sector" (Jeong, 2007). Hence, the aim of this paper is to focus more on the internal side of public sector particularly at the level of employees, who are the concerned parties for the successful implementation of e-government practices and good governance outcomes.

In general, trust has been perceived differently through interpersonal and organizational constructs, where it is based on three main elements, namely fairness, confidence and risk taking (Erturk, 2008). Previously, trust was expressed in terms of expectation level, confidence, willingness and dependency (Rousseau et al., 1998). However, several studies (Ho et al., 2012;; Auh, 2005; Gillespie\& Mann, 2004; Dirks \& Ferrin, 2002; Davis et al., 2000) have found that the performance outcomes of organizations, including efficiency, effectiveness, transparency, openness and knowledge sharing are highly influenced by the trust. Moreover, some researchers found that good governance is a reflection of the good impact of trust on the organizational outcomes (Gillespie \& Mann, 2004; Bijlsma \& Koopman, 2003). For instance, Ellonen et al. (2008) discussed the role of trust on organizational innovativeness which is considered an essential element of good governance. Therefore, when employees trust their organization's abilities, they can come out with innovative ideas to make the service quality delivered by the public sector more effective, efficient and cost saving for both government and customers.

According to Smith (2011), employee's trust can be conceptualized as institutional trust. Thus, when employees trust the organization's regulations, rules and norms, they will be motivated to perform their tasks in a more appropriate mode.

Hence, the objective of this study is to develop a conceptual framework that can serve as a base for future theoretical and empirical researches based on reviewing the previous literature and through the combination of different theories and models related to the implementation of e-government and its impact on employee's trust and good governance.

\section{Theoretical Background}

To provide a useful model for studying the influence of e-government practices on the employee's trust and good governance, different theoretical perspectives were deployed as a foundation for this research. In particular, these perspectives are the diffusion of innovations (DOI) theory, the ICT and Relationship Transformation Model and technology-organization-environment (TOE) framework.

As suggested through the DOI theory, diffusion occurs when individuals, groups and organizations accept innovative ideas or technologies and start to use it (Lippert \& Forman, 2005). Since innovation is broadly defined as an object or idea perceived to be new (Rogers, 2003), the concept of e-government with its novelty can be conceptualized as innovations, where several previous studies such as Sang et al. (2009) and Lean et al. (2009) investigated the adoption of e-government through the DOI theory.

While DOI considers the organizational and the technological factors (Alzuabi, 2012), it was 
suggested by Rogers (1995) that innovation diffusion is based on the perception of the characteristics of the technology and the user's perception of the system. Thus, DOI theory presumes that the decision of adoption is undertaken by the user to improve the operational efficiency (Ramdani et al., 2009; Lippert \& Govindarajulu, 2006). Organizations substitute an exciting process by a new one through diffusion of innovation as a strategy to improve the effectiveness and efficiency of the overall organizational performance. However, the diffusion of e-government through organizations may also be influenced by other factors. Thus combining the two models of ICT and Relationship Transformation Model and TOE could explain this relationship more specifically.

The TOE model was initially developed by Tornatzky and Fleischer (1990), and used as a theoretical model by Ramdani et al. (2013) who recommended it for future studies to explain how the TOE factors can facilitate the diffusion of applications through organizations, including information and communication technology (ICT). In addition to the technological and environmental factors, the organizational factors including human resource development showed that organizations adopting new innovation have more management commitment. Also, utilizing such technologies would change the way businesses are operated in a significant and efficient manner (Ramdani et al., 2013).

Ritchie and Brindley (2005) explained the three complementary perspectives of the ICT and Relationship Transformation Model namely technology, application and relationship perspectives. Technology potential represents the technical capabilities of organization, while application perspective is more concerned with the effective development of human resource at the organization. However, for innovation diffusions to be sustainable, trust among employees and systems should be developed at both internal and external levels.

\section{Literature Review}

Several previous studies have found that e-government practices had a significant impact on promoting good governance among employees while others have failed to associate trust as a mediating effect to enhance good governance (Reychav \& sharkie, 2010; Politis, 2003). According to Smith (2011), it is challenging to develop institutional trustworthiness through the implementation of e-government. Hence, many studies ( $\mathrm{Wu}, 2012$; Crawshaw \& Brodbeck, 2011;) examined trust as a mediator between different variables but the role of employees' trust is still not studied empirically as a mediating variable between e-government practices and good governance in the public sector.

Therefore, this paper tends to highlight the relationships among e-government, employee's trust and good governance as have been discussed in the previous literature

\subsection{Relationship between E-government and Employee's Trust}

The transformation of traditional governments into e-government organizations depends on the capability of the public sector to adapt and take advantage of the emerging information technology. This diffusion has to empower the employees of public sector while using the suitable resources. For instance, Alraja and Alomiam (2013) found a significant relationship between information technology and empowerment of Jordanian public sector as a strategy to 
realize higher economic gains for Jordanian governments. Such empowerment has to build the employee's trust and commitments towards the government, where e-government is claimed to establish trustworthy institutions (Smith, 2011). The relationship between e-government and trust was discussed in literature (Tolbert \& Mossberger, 2006; West, 2005; Parent et al., 2004; West, 2004; Moon, 2003). Most of them were macro-level surveys limited to citizens' perceptions towards governments, but not related to the internal institutional dynamics which contribute to a trustworthy public sector (Smith, 2011).

However, Tolbert and Mossberger (2006) suggested that e-government enhances process-based trust through the improvement of people's interactions and perceptions of responsiveness. This kind of interactions can be at the internal as well as the external level of public sectors.

\subsection{Relationship between E-government and Good Governance}

Recently, governments worldwide have worked to increase the level of openness and transparency as principles of good governance in their performance, where ICTs are considered as suitable means to support openness, efficiency, commitment and transparency and to reduce corruption (Bertot et al., 2010). Conceptually, several studies (Haque \& Pathrannarakul, 2013; Rana et al., 2011; Kettani et al., 2008; Tolbert \& Mossberger, 2006; IOS Press, 2005; Mucavele, 2003; ADB, 2001) state that e-government is a tool developed by the governments to achieve the principles of good and transparent governance such as accountability, responsiveness, efficiency, effectiveness, openness, commitment and transparency. Emperically, Rotchanakitumnuai (2013) and Zoubi et al. (2011) found a positive relationship between e-government and good governance among Thai and Jordanian public organizations respectively.

Also, Navarro et al. (2012) argue that e-government has become essential for the reform of public sector where it assures a transparent and accountable government based on better communication between local and national administrations.

\subsection{Relationship between Employee's Trust and Good Governance}

The relationship between employee's trust and good governance was addressed by several previous studies. Reychav and sharkie (2010) stated that employees' trust within the government authorities in Australia is expressed in the form of interpersonal trust and impersonal trust where it enhance employees' behaviors in terms of participation, decision making and sharing knowledge which are in line to good governance practices. According to Salz (2012), high levels of employee's trust create a more positive working environment through reducing turnover, increasing employee productivity and motivating employees to be committed and caring about the organization. Memiyanty et al. (2010) also claim that both trust and employee's corporation are crucial pillars for reducing governance failure in organizations.

In addition, Kim (2005) found in his study that employee's attributes such as trust and commitment are important factors for any organization to gain the expected outcomes. Employee's trust is built through efficient communication channels and strengthened by the 
accumulated shared information. Smith (2011) considered trust as an essential factor for developing countries, where governments are being transformed and strengthened to obtain their democratic forms of governance. Thus, trustworthy organizations with good governance are essential components of healthy democracies.

Moreover, Semerciöz et al. (2011) explored the effects of both interpersonal and institutional trust on the organizational innovativeness in Pakistan and Turkey. The results indicate that employee's trust was positively related to the strategic innovativeness which is considered an essential element of good governance (Ruhanen et al., 2010; Ellonen et al., 2008). Similarly, Bijlsma and Koopman (2003) claimed that trust plays important role in making the smooth of wide spectrum of organizational process which indicates the effectiveness and efficiency in organizational good governance.

\subsection{Mediating Effect of Employee's Trust between E-government and Good Governance}

Although the implementation of e-government and other ICTs increase efficiency, effectiveness and transparency of public sector services, there are some limitations regarding the improvement of institutional trustworthiness through technological interventions (Smith, 2011). According to Roman-Velazquez (2004), adoption of information technology tools is essential to deliver the best available knowledge to the employees while performing their work. ICT such e-government practices support the efforts of public sector to generate, integrate and transfer knowledge among agency networks (Kim \& Lee, 2006). Moreover, trust and openness in organizational culture encourage such knowledge sharing and enhance communication speed by empowering employees (Ho et al., 2012; Kim \& Lee, 2006). Trust is considered a key for organizations to attain its goals because it enables voluntary employees' cooperation (Bijlsma \& Koopman, 2003).

In addition, Ho et al. (2012) found in his study that social identification and trust at administrative level have a significant mediating effect on the online knowledge sharing among Taiwan organizations. Thus, trust has the potential to assist the public sector and increase effectiveness, efficiency and innovativeness among employees (Mannie et al., 2013; Semerciöz et al., 2011).

On the other hand, Alder et al. (2006) recognized the importance of trust as a mediator between implementation of internet monitoring and employees' job attitudes. Freund (2014) also revealed a strong positive correlation between employees' trust and their total organizational commitment in high technology organizations. The results explain how trust creates a trustworthy environment that encourage employees to corporate and assist others beyond one's work role and with no direct reward. Thus, as trust decreases, employees will be more likely to engage in counterproductive behaviors (Chami \& Fullenkamp, 2002).

Based on the above discussion, a conceptual framework is developed to study the mediating effect of employee's trust between e-government and good governance in public sector as illustrated in Figure1. 


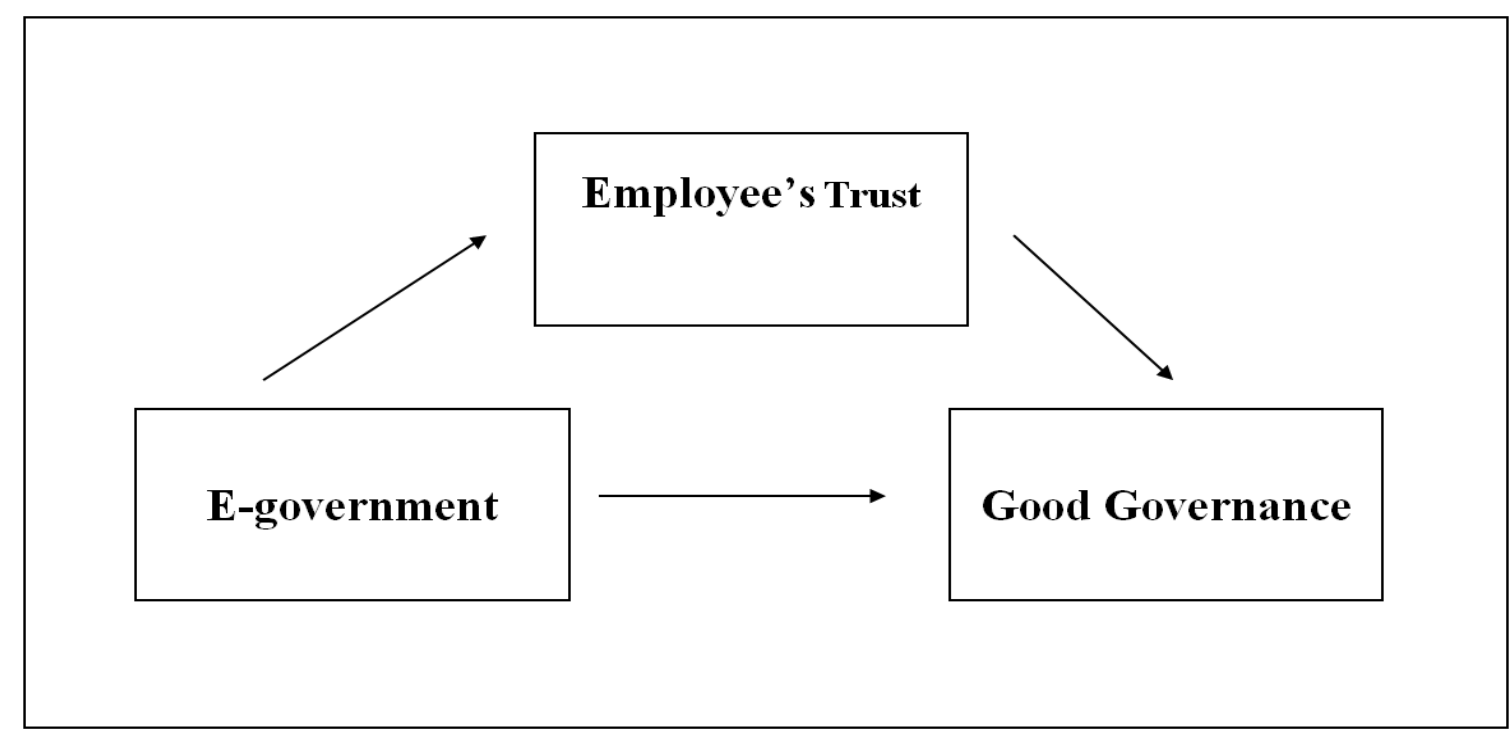

Figure1: Conceptual Research Framework

\section{Conclusion}

This paper has provided a conceptual framework that can serve as a base for further research in the field of e-government, employee's trust and good governance. It is evident that employee's trust aims to promote good governance especially by creating an efficient, effective and transparent working environment through the public sector. Such environment is supported by the e-government practices which ensure a room of innovation and corporation among employees of public sector.

This research was limited to the conceptual literature, thus it would be useful for future studies to focus more on other organizational attitudes such as trust for successful implementation of e-government practices within the public sector. Extending the research to empirical surveys would also contribute to the literature, especially at the level of public sector in the developing countries.

\section{Acknowledgement}

This research was completed at the School of Economic, Finance, and Banking, College of Business at University Utara Malaysia. Thanks for Professor, Dr. Fatimah Wati Ibrahim for her valuable supervision.

\section{References}

ADB. (2001). Toward e-development in Asia and the pacific: A strategic approach for information and communication technology. Asian Development Bank: Strategy and Policy $\begin{array}{lllll}\text { Department. } & \text { Retrieved } & \text { September } & 2013 \text { from }\end{array}$ 
http://www.adb.org/sectors/ict/policies-and-strategies

Alder, S. (2006). Clarifying the effects of Internet monitoring on job attitudes: The mediating role of employee trust. Information \& Management, 43, 894-903.

Alraja, M., \& Alomiam, N. (2013). The effect of information technology in empowerment public sector employees: a field study. Interdisciplinary journal of contemporary research in business, 5, (1), 805-815.

Alzubi, M. (2012). Electronic government adoption model among business organizations in Jordan. Published thesis, University Utara Malaysia.

Alzubi, M. (2012). Electronic government adoption model among business organizations in Jordan. Published thesis, University Utara Malaysia

ANAO. (2003). Better practice public sector governance. National institute for governance, Australian National Audit Office. Retrieved from http://anao.gov.au/ /media/Uploads/Documents/better_practice_public_sector_governance1.p df

Auh, S. (2005).The effects of soft and hard service attributes on loyalty: the mediating role of trust. Journal of Services Marketing, 19 (2), 81-92.

Bertot, C., et al. (2010). Using ICTs to create a culture of transparency: E-government and social media as openness and anti-corruption tools for societies. Government Information Quarterly, 27, 264-271.

Bijlsma, K., \& Koopman, P. (2003). Introduction: trust within organizations. Personnel Review, 32 (5), 543-555.

Chami, R., \& Fullenkamp, C. (2002). Trust and efficiency. Journal of Banking \& Finance, 26, 1785-1809.

Crawshaw, J., \& Brodbeck, F. (2011). Justice and trust as antecedents of careerist orientation. Personal Review, 40(1), 106-125.

Davis, J., et al. (2000). The trusted general manager and business unit performance: empirical evidence of a competitive advantage. Strategic Management Journal, 21, 563-576.

Dirks, K. T., \& Ferrin, D. L. (2002). Trust in leadership: Meta analytic findings and implications for research and practice. Journal of Applied Psychology, 87(4), 611-628.

Ellonen, R. (2008). The role of trust in organizational innovativeness. European Journal of Innovation Management, 11 (2), 160-181.

Ertu“rk, A. (2008). A trust-based approach to promote employees' openness to organizational change in Turkey. International Journal of Manpower, 29 (5), 462-483.

Freund, R. (2014). Determining the effects of employee trust on organizational commitment. Published $\mathrm{PhD}$ thesis at Pepperdine University. ProQuest Dissertation, UMI Number: 3622264. 


\section{I Macrothink}

International Journal of Learning \& Development

ISSN 2164-4063

2014, Vol. 4, No. 3

Gillespie, N., \& Mann, L. (2004). Transformational leadership and shared values: the building blocks of trust. Journal of Managerial Psychology, 19(6), 588-607.

Haque, P., \& Pathrannarakul, P. (2013). E-government towards good governance: A global appraisal. Journal of E-Governance, 36(1), 25-34.

Ho, L., et al. (2012). How social identification and trust influence organizational online knowledge sharing. Internet Research, 22, (1), 4-28.

IOS Press. (2005). The role of e-government in Europe's future. The Journal of E-Government Policy and Regulation, 28(1), 59-68.

Iwu- Egwuonwu, R. (2011). Behavioral governance, accounting and corporate governance quality. Journal of Economics and International Finance. 3(1), 1-12.

Jalaluddin, A., \& Azmizam, A. (2009). The role of efficient urban governance in managing Kuala Lumpur city-region development. Asian Social Science, 5(8), 14-32.

Jeong, C. (2007). Fundamental of Development Administration. Selangor: Scholar Press. ISBN 978-967-5-04508-0

Kettani, D., et al. (2008). Proposition of a method for the development and deployment of e-government systems that emphasize good governance. Proceeding of International MCETECH Conference on e-Technologies, IEEE. DOI 10.1109.

Khan, M. (2013). E-government, GIS and good governance. Public management, 95(1), 18-23.

Kim, H. (2005). IT outsourcing in public organizations: how does the quality of outsourcing relationship affect the IT outsourcing effectiveness? ProQuest Dissertations, UMI: 3193857.

Kim, S., \& Lee, H. (2006). The impact of organizational context and information technology on employee knowledge-sharing capabilities. Public Administration Review, May/June, 370-385.

Kluvers, R. (2010). Mechanisms of accountability in local government: an exploratory study. International Journal of Business and Management, 5(7), 1-8.

Lean, O., et al. (2009). Factors influencing intention to use e-government services among citizens in Malaysia. International Journal of Information Management. 29(6), 458-475.

Lippert, S. K., \& Forman, H. (2005). Utilization of information technology: examining cognitive and experiential factors of post-adoption behavior. IEEE Transactions on Engineering Management, 52(3), 363-381.

Lippert, S. K., \& Govindarajulu, C. (2006). Technological, organizational, and environmental antecedents to web services adoption. Communications of the IIMA, 6(1), 146-158

Mannie, A., et al. (2013). Significant factors for enabling knowledge sharing between government agencies within South Africa. SA Journal of Information Management, 15(2). Available at: http://dx.doi.org/10.4102/sajim.v15i2.569 
Memiyanty, A., et al. (2010). Ethical leadership and employee trust: governance perspective. 848-851. IEEE. DOI: 978-1-4244-6928-4/10

Merchant, S. (2007). Exploring the influence of cultural values on the acceptance of information technology: an application of the technology acceptance model. Issues in Informing Science and Information Technology, 4, 431-443.

Moon, M. (2003). Can it help government to restore public trust? Declining public trust and potential prospects of it in the public sector. In Proceedings of the $36^{\text {th }}$ Hawaii International Conference on System Sciences (HICSS'03), IEEE. Retrieved from http://ieeexplore.ieee.org/xpls/abs_all.jsp?arnumber=1174303\&tag=1

Moti, U. (2007).Building trust in government for good governance: implications for the transformation agenda. Published research at University of Abuja: Nigeria. Retrieved from http://www.academia.edu/1340796/building_trust_in_government_for_good_governance_im plications_for_the_transformation_agenda

Mucavele, F. (2003). Improving the investment climate through e-government and e-land registry in Mozambique. In Proceeding of global forum on international investment; OECD: Johannesburg. Available at: http://www.oecd.org/daf/inv/investmentstatisticsandanalysis/21002025.pdf

Navarro, J., et al. (2012). E-government and citizen's engagement with local affairs through e-websites: The case of Spanish municipalities. International Journal of Information Management, 32, 469-478.

Parent, M., et al. (2005). Building citizen trust through e-government. Government Information Quarterly, 22, 720-736.

Park, S. (2009). An analysis of the technology acceptance model in understanding university students' behavioral intention to use e-learning. Journal of Educational Technology \& Society, $12(3), 150-162$.

Phang, S.N. (2008). Decentralization or Recentralization? Trends in local government in Malaysia. Commonwealth Journal of local governance, 1, 126-132.

Pillay, S. (2004). Corruption: the challenge to good governance; a South African perspective. The International Journal of Public Sector Management, 17(7), 586-605.

Politis, J. (2003). The connection between trust and knowledge management what are its implications for team performance. Journal of Knowledge Management, 7(5), 55-66.

Rachagan, S. (2010). Enhancing corporate governance in listed companies with concentrated shareholdings, a Malaysian perspective. Journal of Financial Crime, 17(4), 430-440.

Ramdani, B., et al. (2009). Predicting SMEs'adoption of enterprise systems. Enterprise Information Management, 22(1/2), 10-24.

Ramdani, B., et al. (2013). SMEs' adoption of enterprise applications A technology-organization-environment model. Journal of Small Business and Enterprise 
Development, 20(4), 735-753

Rana, N., et al. (2011). Reflecting on e-government research: Toward taxonomy of theories and theoretical constructs. International Journal of Electronic Government Research, 7(4), 64-88.

Reychav, I., \& Sharkie, R. (2010). Trust: an antecedent to employee extra-role behavior. Journal of Intellectual Capital, 11(2), 227-247.

Ritchie, B., \& Brindley, C. (2005). ICT adoption by SMEs: implications for relationships and management. New Technology, Work and Employment, 20(3).

Rogers, E. M. (1995). Diffusion of Innovation. New York: Free Press.

Rogers, E.M. (2003). Diffusion of Innovations. $5^{\text {th }}$ Ed. New York: Free Press.

Roman-Velazquez, J. (2004). An empirical study of knowledge management in the government and nonprofit sectors: organizational culture composition and its relationship with knowledge management success and the approach for knowledge flow. Published $\mathrm{PhD}$ thesis at the George Washington University. ProQuest Dissertation, UMI: 3122159.

Rotchanakitumnuai, S. (2013). The governance evidence of e-government procurement. Transforming Government: People, Process and Policy, 7(3), 309-321.

Rousseau, D., et al. (1998). Not so different after all: a cross-discipline view of trust. Academy of Management Review, 23(3), 393-404.

Ruhanen, et al. (2010). Governance: a review and synthesis of the literature. Tourism Review, 65(4), 4-16.

Salz, T. (2012). Employee trust key to a strong practice. Retrieved August 10, 2014 from http://medicaleconomics.modernmedicine.com/medical-economics/news/modernmedicine/m odern-medicine-feature-articles/employee-trust-key-strong-pra?page=full\#sthash.BR40xarx.d puf

Sang, S., et al. (2009). E-Government Adoption in ASEAN: the Case of Cambodia. Internet Research, 19(5), 517-534.

Semerciöz, F., et al. (2011). An Empirical Study on the Role of Interpersonal and Institutional Trust in Organizational Innovativeness. International Business Research, 4 (2), 125-136.

Shean, R. (2010). Company secretary: good governance, a tool for better management and outcomes. Keeping Good Companies, 62(4), 196-204.

Siddiqia, S. (2009). Framework for assessing governance of the health system in developing countries: Gateway to good governance. Health Policy, 90, 13-25.

Smith, M. (2011). Limitations to building institutional trustworthiness through e-government: a comparative study of two e-services in Chile. Journal of Information Technology, 26, 78-93. 


\section{Macrothink}

International Journal of Learning \& Development

ISSN 2164-4063

2014, Vol. 4, No. 3

Tait, M., \& Hansen, C. (2013). Trust and governance in regional planning. TPR, 84(3), 283-312. DOI:10.3828/tpr.2013.17.

Tolbert, C., \& Mossberg, K. (2006). The effects of e-government on trust and confidence in government. Public Administration Review, 66(3), 302-478.

Tornatzky, L.G., \& Fleischer, M. (1990). The process of technological innovation. Lexington Books :Lexington, MA.

UNDP. (2008). A guide to UNDP democratic governance practice. United Nations Development Program. Retrieved October 3, 2013 from http://www.undp.org/content/dam/aplaws/publication/en/publications/democratic-governance /dg-publications-for-website/a-guide-to-undp-democratic-governance-practice-/DG_FinalMa ster2-small.pdf

UNESCAP. (2012). What is good governance? United Nations Economic and Social Commission for Asia and the Pacific. Retrieved October 3, 2013 from www.uniscap.org/huest/gg/governance.htm

Wangpipatwong, S. (2008). Understanding citizen's continuance intention to use e-government website: a composite view of technology acceptance model and computer self-efficacy. The Electronic Journal of e-Government, 6(1), 55 - 64.

Warkentin, M. (2002). Encouraging citizen adoption of e-government by building trust. Electronic Markets, 12 (3), 157-162.

West, D. (2004). E-government and the transformation of service delivery and citizen attitudes. Public administration review, 64(1), 15-27.

West, D.M. (2005), Digital government: Technology and public sector performance, Princeton University Press, Princeton, NJ.

$\mathrm{Wu}$, M. (2012). Moral leadership and work performance: testing the mediating and interaction effects in China. Chinese Management Studies, 6(2), 284-299.

\section{Copyright Disclaimer}

Copyright reserved by the author(s).

This article is an open-access article distributed under the terms and conditions of the Creative Commons Attribution license (http://creativecommons.org/licenses/by/3.0/). 